\title{
Prevalence of Childhood Overweight and Obesity and its Determinant Factors Among Elementary School Children in Addis Ababa, Ethiopia: A Cross Sectional Study
}

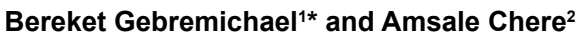

${ }^{1}$ Department of Nursing, College of Medicine and Health Sciences, Madawalabu University, Bale Goba, Ethiopia

${ }^{2}$ Department of Nursing and midwifery, Allied school of health science, Addis Ababa University, Addis Ababa, Ethiopia

\begin{abstract}
Background: Obesity and overweight pose major risk for serious diet-related chronic diseases, including Type 2 diabetes, cardiovascular disease, hypertension and stroke, and certain forms of cancer. Even though there is no well-documented information recently, chronic diseases that are directly or indirectly related to overweight and obesity are increasing in Ethiopia especially in urban areas.
\end{abstract}

Objective: the main aim of this study is to determine the prevalence of childhood overweight and obesity and its determinant factors.

Methods: A cross-sectional survey was conducted among 463 elementary school children in Addis Ababa Study participants were selected using multi stage sampling from 10 public and 10 private elementary Schools. Overweight and obesity was determined using CDC 2000, BMI percentile chart. Socio-demographic and other determinants of childhood overweight were assessed. Data were collected using combination of interview of children and self-administered questionnaire to their parents. Finally data were processed and analysed using Epi info version 3.5.4and SPSS version 21.

Result: A total 463 children and 463 parents participated in the study. The overall prevalence of underweight, normal, overweight and obesity is $44(9.5 \%), 360(77.8 \%), 46(9.9 \%)$ and $13(2.8 \%)$ respectively. Sex specific prevalence of overweight and obesity shows $7.7 \%$ and $3.2 \%$ for male and $12 \%$ and $2.5 \%$ for female respectively. Significant association with overweight was observed among car ownership of the family $(p<0.001)$, number of snacks per day $(p=0.03)$, sweet food preference $(p<0.001)$, buying ice cream $(p=0.014)$, eating breakfast irregularly $(p=0.034)$, walking or riding bicycle for at least 10 minutes per day $(p=0.009)$ and family participation in regular physical activity $(p=0.023)$.

Conclusion and Recommendations: The prevalence of overweight was found to be high even comparable with the global prevalence. Among the factors identified are unhealthy dietary pattern like preferring sweet foods, eating breakfast irregularly, buying ice cream and frequent snacking are strongly associated with overweight. In addition physical inactivity are also important factors impacting on the risk of obesity in children. If Primary preventive measures is not taken immediately, prevalence of overweight and obesity among children in Addis Ababa might increase rapidly in the coming few years. Early interventions on modifiable risk factors by promoting active lifestyles and healthy diets are likely to decrease the rate of childhood obesity.

Keywords: Overweight; Obesity; Children

\section{Background}

Obesity has become a global health problem. Obesity and overweight pose a major risk for serious diet-related chronic diseases, including Type 2 diabetes, cardiovascular disease, hypertension and stroke, and certain forms of cancer [1].

The World Health Organization (WHO) estimated that by 2005 , at least 1.6 billion and 400 million people aged above 15 years were overweight and obese respectively. It further projected that by 2015 , these statistics will increase to 2.3 billion for overweight and 700 million for obesity unless drastic measures are taken to mitigate this burgeoning problem [2].

In Africa, despite a high prevalence of under nutrition, the prevalence of overweight is increasing at an alarming rate. It is estimated that $25 \%$ to $60 \%$ of urban women are overweight [3].

The prevalence of overweight and obesity is also rapidly increasing among children. The International Obesity Task Force (IOTF) estimates that about 155 million school-going children globally are either overweight or obese [4]. WHO define children as population age group less than eighteen.
Childhood obesity is considered to be a precursor of adverse health effects in adulthood, as overweight children are more likely to become overweight adolescents and adults; 2.8 times more likely in one study in Chinese children [5].

Furthermore, rapid changes in diets and lifestyles that have occurred with industrialization, urbanization, economic development and market globalization have accelerated over the past decade. This is having a significant impact on the health and nutritional status of population, particularly in developing countries and countries

*Corresponding author: Bereket G/Michael, Department of Nursing, College of Medicine and Health Sciences, Madawalabu University, Bale Goba, Ethiopia, Tel: +251912660125; E-mail: bdpapi3@gmail.com

Received May 27, 2015; Accepted June 20, 2015; Published June 25, 2015

Citation: Gebremichael B, Chere A (2015) Prevalence of Childhood Overweight and Obesity and its Determinant Factors Among Elementary School Children in Addis Ababa, Ethiopia: A Cross Sectional Study. J Nutr Disorders Ther S1: 002. doi:10.4172/2161- 0509.S1-002

Copyright: (c) 2015 Gebremichael B, et al. This is an open-access article distributed under the terms of the Creative Commons Attribution License, which permits unrestricted use, distribution, and reproduction in any medium, provided the original author and source are credited. 
in transition [6]. In 2005 WHO launched a campaign calling for increased global investment to prevent the growth of chronic disease in developing countries [7].

Despite the fact poverty, nutrition deficiency and unhygienic living condition are major problems in the developing countries, chronic disease that are directly related to overweight and obesity are emerging in an alarming rate. In spite of this scenario people are not using preventive measures against obesity, but they only depend on their daily routine work $[8]$.

According to the study conducted in Addis Ababa in 2007 prevalence of overweight and obesity among primary school children in Addis Ababa were $7.6 \%$ ( $95 \% \mathrm{CI}=5.85,9.37 \%)$ and $0.9 \%$ $(95 \% \mathrm{CI}=0.027 \%, 1.53 \%)$ respectively. The sex specific prevalence of overweight and obesity were 9.4 and 0.8 for females, $5.4 \%$ and 1.1 for boys respectively. The prevalence of overweight in private school was $23.2 \%(95 \% \mathrm{CI}=14.71 \%, 31.69 \%)$. Whereas the overall prevalence of underweight was $13 \%$ (18.1\% in boys and 9\% in girls) [9-14].

Even though there is no well-documented information recently, chronic diseases become Increasing in Ethiopia especially in urban areas. In Addis Ababa it becomes common to see overweight people in all age group including school children. As far as our knowledge is concerned there is only two documented study done to assess prevalence and determinants of childhood and adolescent overweight and obesity in Addis Ababa. Limited number of research in this area motivates us to select this topic. Though, there is a lack of data concerning overweight and obesity assessment in childhood and adolescence in Ethiopia, clearly the risk of childhood obesity leading to adult morbidity is of great public health significance [15-20].

Due to the above circumstances this study is designed to measure the prevalence of childhood overweight and effect of socio-demographic and life style factors on childhood overweight to stimulate planners and researchers on double burden of disease in Ethiopia which is less recognized problem. As a result this study will have great contribution on designing preventive action of early age overweight and obesity [2124].

\section{Operational Definition}

\section{Overweight}

BMI for age greater than or equal to 85th percentile but less than 95th percentile according the CDC 2000 growth chart.

\section{Obesity}

BMI for age greater than or equal to 95th percentile according the CDC 2000 growth chart.

\section{Moderate exercise}

Low-impact aerobic exercise classes, brisk walking or hiking, recreational team sports (volleyball, soccer, etc.).

\section{Vigorous exercise}

Running or jogging, high-intensity aerobic classes, competitive full-field sports (soccer) or basketball.

\section{Children}

Population that exist in the age group between 10 to 18 years of age [25].

\section{Methods and Materials}

\section{Study design}

Cross-sectional survey of childhood overweight and obesity and its determinant factor was conducted.

\section{Study area and period}

The study was conducted in Addis Ababa from April 20 to May 7, 2014. Addis Ababa is the capital city of Ethiopia with a great diversity of ethnicity almost home of all ethnicity found in the country. The city is divided in to 10 administrative sub cities namely: Arada, Yeka, Gulele, Addis Ketema, Akaki-kality, Nefassilk-Lafto, Lideta, Bole, Kolfe-keranio and Kirkos. The study included all sub cities. According to 2011/12 report of Addis Ababa Educational Bureau of City Government, there are 765 primary schools. In all this school there are a total of 487,344 students. From the total number of school $15.03 \%$ are owned by government sector and $84.97 \%$ are owned by private sector. The study was conducted in 20 selected schools from all sub cities of which 11 were government school and 9 were private.

\section{Source population and study population}

The source populations were all elementary school students living in Addis Ababa. Elementary school students from grade 5-8 in 2013/14 academic year were the study population.

\section{Sample size determination}

The study employed single population proportion sample size determination formula given below.

$$
\mathrm{n}=\frac{\mathrm{z} \alpha / 2^{2} \mathrm{p}(1-\mathrm{p})}{\mathrm{d}^{2}}
$$

Where: $\mathrm{n}$ - is the minimum sample size required

p- Is an estimate of the proportion of the overweight in the population

\section{d- Margin of error for sampling}

Z- The standard normal value at $(100 \%-\alpha)$ confidence level.

In this study we consider $\mathrm{P}=10 \%$ (global prevalence of child hood overweight)

$$
\begin{aligned}
& \mathrm{d}=4 \% \\
& \mathrm{n}=\frac{(1.96)^{2} 0.1(1=0.1)}{0.04^{2}} \\
& \mathrm{n}=217+22(10 \% \text { of non-respondent })=239
\end{aligned}
$$

Since multistage sampling was employed, the calculated sample was multiplied by 2 for design effects to control the effect of sampling that could happen due to using sampling method other than simple random sampling. After all, the final sample size became 478 .

\section{Sampling procedure}

In Addis Ababa there are 10 sub cities, from each sub city one private and one government school were selected by simple random sampling. Only one school administration refused to participate in the study due to this reason another school were selected in the same method from the same sub city. From each school an average of 24 students were selected which in some cases were modified based on their population proportion until it meets the sample size. Since the 
study group range from 10-18 years of age, the study participants were selected from grade 5-8. From each grade level one section was selected and from each selected class an average of 6 students was selected by simple random method by making male to female ratio proportional.

When any of the selected participant or their family were not willing to participate on the study another student from the same section with the same sex were selected by lottery method.

\section{Data collection tools}

Semi structured questionnaire were used to collect the data. Most of the questions were adapted and modified from previous study $[9,26]$. The questionnaires were first developed in English and were translated in to local language (Amharic) and review was made by different expertise for consistency of translation of the language. Training was given to data collector and supervisor by principal investigator for Two days. Pre-test and demonstration of instrument was performed at each school for each data collector. Socio-demographic variables: family size, family monthly income, sex of participant child, education level of head of the house hold, ethnicity and possession of car was collected from student family using self-administered questionnaire. Physical activity and eating habit was assessed by interview using questionnaire. Weight was measured by water bath scale. Height measurement was conducted using height measuring board.

Before application the instrument was checked by external tap meter for its accuracy.

\section{Data collection procedure and quality control}

Support letter written by Addis Ababa University (AAU) was given for each school principal and permission was requested. In those schools in which we got permission, selections of classes were made. Data collectors and supervisors were recruited with minimum qualification of diploma in any health related fields. Training was given on how to fill questioners and how to take measurement.

After class selection performed in each school, each respective class room teachers in selected class and PI gave orientation to the study participant. The selected students were given parental selfadministered questionnaire with consent form to their parents. Those students whose parents consented and returned the questionnaire were further interviewed and their height and weight measurements were taken.

\section{Inclusion and exclusion criteria}

Students from grade 5-8 and who give assent (were willing to participate in the study) were included in the study and students from grade 1-4 were excluded in the sample, because students at this level may not respond correctly to the prepared questionnaire. Disable children who are difficult to any physical measurement were excluded. Children is usually refers to age group less than or equal to 18 years old. Any refusal either from parent or student made participant to be excluded from the study [27-29].

Training of data collectors were carried out. Demonstration of interview through and taking measurement was done for each data collectors on one participant to reduce enter observer error. Weight scale was calibrated at 0 with no object on it and placed in level surface before measurement is carried out. Continuous check-up of scales were performed for their reliability. Data collection was supervised for correct implementation of procedures by the principal investigator. The principal investigator supervised and reviewed every questionnaire for completeness and logical consistency and correction was made in the field. Data coding, entry and cleaning was performed by the principal investigator.

\section{Data processing and analysis}

Data was entered and analysed by EPI Info version 3.5.4 and SPSS version 21. Body mass index (BMI) was calculated by; BMI = weight (kg)/height square (M2) using Excel 2010 program. BMI percentiles for age were determined separately for male and female using CDC growth charts developed in 2000 [30].

We select BMI from other methods because of its simplicity and popularity and ability to measure all ranges of nutritional status from underweight to obesity. Variation of overweight with sociodemographic variables, dieting habit, and physical activity was analysed using descriptive statistics to see percentage distribution of overweight over those determinants. To evaluate significance of difference, $95 \%$ confidence interval for odds ratio was used. To control effect of confounding and predict the effect of some variables, binary logistic regression was performed [31-35].

\section{Ethical clearance/consent/ confidentiality}

The proposal was approved by ethical Review Committee of Addis Ababa University, College of Medicine and Health Sciences. Support letter, written by the Committee was given to Addis.

Ababa education bureau and each selected school. After getting permission from school, each subject in selected classes was given a written consent form to take home to their parents or guardians. If the parents of the selected students were willing to participate in the study, the child was included in the study. If they were not willing the child was replaced by another willing participant $[36,37]$.

\section{Result}

\section{Socio demographic characteristics}

A total of 478 children from 20 schools (10 private and 10 government schools) were selected to participate in the study, of which 463 participated in the study which gives $96.9 \%$ response rate.

The socio demographic characteristics of children participated in the study is shown in (Table 1). Of the 463 children participants 221 (47.7\%) were Male and 242 (52.3\%) were Female and 306 (66.1\%) were between the age of 10-14 and 157 (33.9\%) in the age group 15-18 years. Composition of study participant by school type shows 209 (45.1\%) were from private school and 254 (54.9\%) were from government school.

\section{Prevalence of overweight and obesity}

The overall prevalence of underweight, normal, overweight and obesity is 44 (9.5\%), $360(77.8 \%), 46(9.9 \%)$ and $13(2.8 \%)$ respectively. The distribution of underweight, overweight and obesity by age, sex and school type is depicted in (Table 2). From a total of 221 male study participants $22(9.9 \%)$ were under weight, $17(7.7 \%)$ were overweight and $7(3.2 \%)$ were obese. $22(9.1 \%), 29(12 \%)$ and $6(2.5 \%)$ out of 242 female participants were underweight, overweight and obese respectively. According to the distribution shown above girls are more over weight than boys whereas boys are slightly obese. Younger children at age $10-14$ are more underweight $36(11.8 \%)$ than $8(5.1 \%)$ older children 15-18 years age classification. They also have lower Proportion of overweight 29 (9.5\%) but higher proportion of obese 13 (4.5\%). 


\begin{tabular}{|c|c|c|c|}
\hline Variables & Level & $\begin{array}{c}\text { Number of } \\
\text { student } n=463\end{array}$ & Percent (\%) \\
\hline Sex & $\begin{array}{l}\text { Male } \\
\text { Female }\end{array}$ & $\begin{array}{l}221 \\
242\end{array}$ & $\begin{array}{l}47.7 \\
52.3\end{array}$ \\
\hline Age & $\begin{array}{l}10-14 \\
15-18\end{array}$ & $\begin{array}{l}306 \\
157\end{array}$ & $\begin{array}{l}66.1 \\
33.9\end{array}$ \\
\hline School type & $\begin{array}{c}\text { Private } \\
\text { Government }\end{array}$ & $\begin{array}{l}209 \\
254\end{array}$ & $\begin{array}{l}45.1 \\
54.9\end{array}$ \\
\hline Sub city of living & $\begin{array}{l}\text { Addis ketema } \\
\text { Akaki kality } \\
\text { Arada } \\
\text { Bole } \\
\text { Gulelie } \\
\text { Kirkos } \\
\text { Kolfe keranio } \\
\text { Lideta } \\
\text { Nefas silk-Lafto } \\
\text { Yeka }\end{array}$ & $\begin{array}{l}47 \\
45 \\
49 \\
47 \\
43 \\
46 \\
46 \\
47 \\
49 \\
44\end{array}$ & $\begin{array}{c}10.2 \\
9.7 \\
10.6 \\
10.2 \\
9.3 \\
9.9 \\
9.9 \\
10.2 \\
10.6 \\
9.4\end{array}$ \\
\hline Religion & $\begin{array}{l}\text { Orthodox } \\
\text { Muslim } \\
\text { Protestant } \\
\text { Catholic }\end{array}$ & $\begin{array}{l}293 \\
117 \\
23 \\
30\end{array}$ & $\begin{array}{c}63.3 \\
25.3 \\
5.0 \\
6.5\end{array}$ \\
\hline Ethnicity & $\begin{array}{c}\text { Amara } \\
\text { Oromo } \\
\text { Gurage } \\
\text { Tigre } \\
\text { Others }\end{array}$ & $\begin{array}{l}208 \\
85 \\
118 \\
31 \\
21\end{array}$ & $\begin{array}{c}44.9 \\
18.4 \\
25.5 \\
6.7 \\
4.5\end{array}$ \\
\hline Educational status & $\begin{array}{l}\text { Read and write } \\
\text { Primary education } \\
\text { Secondary education } \\
\text { Higher education }\end{array}$ & $\begin{array}{c}14 \\
77 \\
180 \\
192\end{array}$ & $\begin{array}{c}3.0 \\
16.6 \\
38.9 \\
\\
41.5\end{array}$ \\
\hline $\begin{array}{c}\text { Income of the house } \\
\text { hold( In ETB) }\end{array}$ & $\begin{array}{c}\leq 150 \\
151-650 \\
651-1400 \\
1401-2350 \\
2351-3550 \\
3551-5000 \\
>5000\end{array}$ & $\begin{array}{c}8 \\
58 \\
55 \\
81 \\
79 \\
94 \\
88\end{array}$ & \begin{tabular}{|c|}
1.7 \\
12.5 \\
11.9 \\
17.5 \\
17.1 \\
20.3 \\
19.0
\end{tabular} \\
\hline Car ownership & $\begin{array}{l}\text { Yes } \\
\text { No }\end{array}$ & $\begin{array}{c}99 \\
364\end{array}$ & $\begin{array}{l}21.4 \\
78.6\end{array}$ \\
\hline
\end{tabular}

Table 1: Socio demographic characteristics of participants among Elementary school children in Addis Ababa, in 2014.

The proportion of underweight is less for child from car owner family than those who don't own. Which is $6(6.1 \%)$ for car owner and $38(10.4 \%)$ for those who don't. 7 (1.9\%) of children whose family do not own car are overweight which is remarkably lower than those who own car 39 (39.4\%). The same is true for obesity $12(12.1 \%)$ and $1(0.2 \%)$ for those who have car and for those who don't respectively.

\section{Socio demographic factors related to overweight}

Socio demographic related of the child and their parents in association with overweight are described in (Table 3). According to the result females were slightly overweight than male which is 1.6 times higher than male at $(95 \% \mathrm{CI} 0.87,3.06)$. Private school children were at higher risk to overweight than government school. They are 6.8 times at higher risk than government school students (95\%CI 3.15, 15.01). older children aged 15-18 were also found to have slightly more risk to be overweight than younger aged 10-15, which is 1.6 times higher in older children (95\%CI 0.6,2.2).

Children from families who own car was found to be significantly overweight than children from family who do not own car. Children from car owner family were 33 times more likely to be overweight than those who do not (95\%CI 14.2,77.5).

\section{Eating habit and food choice}

Dieting habit of the respondents shows $5(1.1 \%)$ of the respondent do not consume vegetable while 285 (61.6\%) eat vegetable 1-2 times per week, 135 (29.2\%) eats 3-4 times per week, and 38 (8.2\%) eats 5-7 times per day. The frequency for the consumption of fruit shows $8(1.7 \%)$ did not consume fruit, 285 (61.6\%) consume 1-2 times per week, 130 (28.1\%) consume 3-4 times per week, 40 (8.5\%) consume 5-7 times per week.

The food preference of the participant as they are requested to list five food they prefer to eat most was asked and classified. The result revealed that $421(90.0 \%)$ mention that is classified as animal product as their preferred food, $410(88.6 \%)$ reported food that are rich in carbohydrate in their preference list, $82(17.7 \%)$ listed sweet foods in their preference list, 359 (77.5\%) and 419 (90.5\%) of the respondent did not mention at least one vegetable or fruit in their preference list.

Out of the entire study participant $62(13.4 \%)$ did not use snack, $325(70.2 \%)$ use snack once in a day, 67 (14.5\%) and 9(1.9\%) use snack twice and three times a day respectively. The food buying habit of the study participant in addition to the regular diet type and schedule depicted $332(71.7 \%)$ of the total respondent bought cake, 374 (80.8\%) biscuit, 197 (42.5\%) ice cream and 176 (38.0\%) chocolate.

(Table 4) Describe diet related factors associated with overweight among children in Addis Ababa. The result depicted eating snack has strong association with overweight. As the number of snack per day increase the risk to be overweight increases in significant manner. Children who eat snack are 1.7 times at high risk than those who do not $(95 \%$ CI $0.6,4.9)$. Children who eat snack 3 times per day and 2 times are 26 and 10 times at higher risk respectively than those who eat 1 times per day.

The food buying behaviour of the study participant shows buying cake, chocolate, biscuit and ice cream have significantly strong association with overweight. Children who buy cake are 3.5 times more vulnerable to be overweight than those who do not (95\% CI 1.4, 9.2). Children who buy biscuit are 5.8 times more risk than those who do not (95\% CI 1.4, 24.4). Buying ice cream and chocolate is 11 and 6.2 times more risk than those who don't buy.

\begin{tabular}{|c|c|c|c|c|c|}
\hline Variable & Level & $\begin{array}{c}\text { Under weight } \\
(\%)\end{array}$ & $\begin{array}{c}\text { Normal weight } \\
(\%)\end{array}$ & $\begin{array}{c}\text { Overweight } \\
(\%)\end{array}$ & $\begin{array}{l}\text { Obesity } \\
\text { (\%) }\end{array}$ \\
\hline Sex & $\begin{array}{l}\text { Male } \\
\text { Female }\end{array}$ & $\begin{array}{l}22(9.9 \%) \\
22(9.1 \%)\end{array}$ & $\begin{array}{l}175(79.2 \%) \\
185(76.4 \%)\end{array}$ & $\begin{array}{l}17(7.7 \%) \\
29(12 \%)\end{array}$ & $\begin{array}{l}7(3.2 \%) \\
6(2.5 \%)\end{array}$ \\
\hline Age & $\begin{array}{l}10-14 \\
15-18\end{array}$ & $\begin{array}{c}36(11.8 \%) \\
8(5.1 \%)\end{array}$ & $\begin{array}{l}228(74.5 \%) \\
132(84.1 \%)\end{array}$ & $\begin{array}{c}29(9.5 \%) \\
17(10.8 \%)\end{array}$ & $\begin{array}{c}13(4.2 \%) \\
0(0 \%)\end{array}$ \\
\hline School type & $\begin{array}{c}\text { Private } \\
\text { Government }\end{array}$ & $\begin{array}{c}18(8.6 \%) \\
26(10.2 \%)\end{array}$ & $\begin{array}{l}143(68.4 \%) \\
217(85.5 \%)\end{array}$ & $\begin{array}{c}38(18.2 \%) \\
8(3.1 \%)\end{array}$ & $\begin{array}{c}10(4.8 \%) \\
3(1.2 \%)\end{array}$ \\
\hline $\begin{array}{c}\text { Car ownership of the } \\
\text { family }\end{array}$ & $\begin{array}{l}\text { Yes } \\
\text { No }\end{array}$ & $\begin{array}{c}6(6.1 \%) \\
38(10.4 \%)\end{array}$ & $\begin{array}{c}42(42.4 \%) \\
318(87.4 \%)\end{array}$ & $\begin{array}{c}39(39.4 \%) \\
7(1.9 \%)\end{array}$ & $\begin{array}{c}12(12.1 \%) \\
1(0.2 \%)\end{array}$ \\
\hline
\end{tabular}

Table 2: Distribution of underweight, overweight, and obesity by socio demographic among primary school children in Addis Ababa, 2014 . 
Citation: Gebremichael B, Chere A (2015) Prevalence of Childhood Overweight and Obesity and its Determinant Factors Among Elementary School Children in Addis Ababa, Ethiopia: A Cross Sectional Study. J Nutr Disorders Ther S1: 002. doi:10.4172/2161- 0509.S1-002

Page 5 of 9

\begin{tabular}{|c|c|c|c|c|c|}
\hline \multirow{2}{*}{ Variables } & \multirow{2}{*}{ Level } & \multicolumn{2}{|c|}{ Proportion } & \multirow{2}{*}{$\operatorname{COR}(95 \% \mathrm{Cl})$} & \multirow{2}{*}{ P-value } \\
\hline & & Overweight (\%) & Not overweight (\%) & & \\
\hline \multirow{2}{*}{ Sex } & Male & $204(92 \%)$ & $12(7 \%)$ & 1 & \\
\hline & Female & $213(88 \%)$ & $29(12 \%)$ & $1.634(0.871-3.064)$ & 0.126 \\
\hline \multirow{2}{*}{ School Type } & Government & $246(97 \%)$ & $8(3 \%)$ & 1 & \\
\hline & Private & $171(82 \%)$ & $38(18 \%)$ & $6.833(3.111-15.011)$ & $<0.001$ \\
\hline \multirow{2}{*}{ Age } & $10-14$ & $277(90 \%)$ & $29(10 \%)$ & 1 & \\
\hline & $15-18$ & $140(90 \%)$ & $17(10 \%)$ & $1.16(0.616-2.183)$ & 0.646 \\
\hline \multirow{5}{*}{ Ethnicity } & Amhara & $186(90 \%)$ & $22(10 \%)$ & $0.503(0.155-1.628)$ & 0.251 \\
\hline & Oromo & $81(95 \%)$ & $4(5 \%)$ & $0.210(0.048-0.923)$ & 0.039 \\
\hline & Gurage & $106(90 \%)$ & $12(10 \%)$ & $0.481(0.139-1.666)$ & 0.248 \\
\hline & Tigre & $27(88 \%)$ & $4(12 \%)$ & $0.630(0.139-2.859)$ & 0.549 \\
\hline & Others & $17(80 \%)$ & $4(20 \%)$ & 1 & \\
\hline \multirow{2}{*}{ Car ownership } & Yes & $60(61 \%)$ & $39(39 \%)$ & $33.1(14.2-77.5)$ & $<0.001$ \\
\hline & No & $357(99 \%)$ & $7(1 \%)$ & 1 & \\
\hline
\end{tabular}

Table 3: Socio demographic related factor of the children and their parents in association with overweight among elementary school children in Addis Ababa, 2014.

\begin{tabular}{|c|c|c|c|c|c|}
\hline \multirow{2}{*}{ Variables } & \multirow{2}{*}{ Level } & \multicolumn{2}{|c|}{ Proportion } & \multirow{2}{*}{$\operatorname{COR}(95 \% \mathrm{Cl})$} & \multirow{2}{*}{ P-value } \\
\hline & & Overweight & Not overweight & & \\
\hline \multirow{2}{*}{ Do you eat snack } & Yes & $359(89.5 \%)$ & $42(10.5 \%)$ & $1.696(0.586-4.908)$ & 0.330 \\
\hline & No & $58(93 \%)$ & $4(7 \%)$ & 1 & \\
\hline \multirow{3}{*}{ How many times do you eat snack per day } & 1times & $310(9 \%)$ & $15(5) \%$ & 1 & \\
\hline & 2times & $45(67 \%)$ & $22(33 \%)$ & $10.104(4.884-20.902)$ & $<0.001$ \\
\hline & 3times & $4(44 \%)$ & $5(56 \%)$ & 25.833(6.287-64.152) & $<0.001$ \\
\hline \multicolumn{6}{|l|}{ Food bought by the participants } \\
\hline Cake & $\begin{array}{l}\text { Yes } \\
\text { No }\end{array}$ & $\begin{array}{l}291(8 \%) \\
126(9 \%)\end{array}$ & $\begin{array}{c}41(12 \%) \\
5(4 \%)\end{array}$ & $\begin{array}{c}3.551(1.371-9.196) \\
1\end{array}$ & 0.009 \\
\hline biscuit & $\begin{array}{l}\text { Yes } \\
\text { No }\end{array}$ & $\begin{array}{l}330(8 \%) \\
87(98 \%)\end{array}$ & $\begin{array}{r}44(12 \%) \\
2(2 \%)\end{array}$ & $\begin{array}{c}5.800(1.379-24.397) \\
1\end{array}$ & 0.016 \\
\hline chocolate & $\begin{array}{l}\text { Yes } \\
\text { No }\end{array}$ & $\begin{array}{l}141(80 \%) \\
276(96 \%)\end{array}$ & $\begin{array}{c}35(20 \%) \\
11(4 \%)\end{array}$ & $\begin{array}{c}6.228(3.071-12.633) \\
1\end{array}$ & $<0.001$ \\
\hline Ice cream & $\begin{array}{l}\text { Yes } \\
\text { No }\end{array}$ & $\begin{array}{l}157(80 \%) \\
260(98 \%)\end{array}$ & $\begin{array}{c}40(20 \%) \\
6(2 \%)\end{array}$ & $\begin{array}{c}11.040(4.576-26.634) \\
1\end{array}$ & $<0.001$ \\
\hline \multirow{3}{*}{ Eating while going to cinema } & Yes & $58(63 \%)$ & $34(37 \%)$ & $8.090(3.750-17.452)$ & $<0.001$ \\
\hline & No & $221(99 \%)$ & $2(1 \%)$ & $0.125(0.027-0.578)$ & 0.008 \\
\hline & I don't go & $138(93 \%)$ & $10(7 \%)$ & 1 & \\
\hline \multicolumn{6}{|l|}{ Extra eating habits } \\
\hline \multirow{3}{*}{ Eating while watching TV } & Yes & $129(80 \%)$ & $32(20 \%)$ & $1.426(0.461-4.416)$ & 0.538 \\
\hline & No & $265(96 \%)$ & $10(4 \%)$ & $0.217(0.063-0.746)$ & 0.015 \\
\hline & I don't go & $23(85 \%)$ & $4(15 \%)$ & 1 & \\
\hline \multirow{2}{*}{ Eating food while studying } & Yes & $142(83 \%)$ & $29(17 \%)$ & $3.304(1.756-6.216)$ & $<0.001$ \\
\hline & No & $275(94 \%)$ & $17(6 \%)$ & 1 & \\
\hline \multirow{2}{*}{ Eating breakfast regularly } & Yes & $303(88 \%)$ & $41(12 \%)$ & 1 & \\
\hline & No & $114(95 \%)$ & $5(5 \%)$ & $0.324(0.125-0.841)$ & 0.021 \\
\hline \multirow{2}{*}{ Irregular eating habit } & Yes & $148(87 \%)$ & $22(13 \%)$ & $1.666(0.903-3.073)$ & 0.102 \\
\hline & No & $269(92 \%)$ & $24(8 \%)$ & 1 & \\
\hline \multicolumn{6}{|l|}{ Preferred food list } \\
\hline Vegetable & $\begin{array}{l}\text { Yes } \\
\text { No }\end{array}$ & $\begin{array}{l}103(99 \%) \\
314(87 \%)\end{array}$ & $\begin{array}{c}1(1 \%) \\
43(13 \%)\end{array}$ & $\begin{array}{c}1 \\
14.761(2.016-67.428)\end{array}$ & 0.008 \\
\hline Fruit & $\begin{array}{l}\text { Yes } \\
\text { No }\end{array}$ & $\begin{array}{c}41(93 \%) \\
376(90 \%)\end{array}$ & $\begin{array}{c}3(7 \%) \\
43(10 \%)\end{array}$ & $\begin{array}{c}1 \\
1.563(0.464-5.262)\end{array}$ & 0.471 \\
\hline Sweet foods & $\begin{array}{l}\text { Yes } \\
\text { No }\end{array}$ & $\begin{array}{l}46(56 \%) \\
371(97 \%)\end{array}$ & $\begin{array}{c}36(44 \%) \\
10(3 \%)\end{array}$ & $\begin{array}{c}29.035(13.515-62.735) \\
1\end{array}$ & $<0.001$ \\
\hline Carbohydrate diet & $\begin{array}{l}\text { Yes } \\
\text { No }\end{array}$ & $\begin{array}{c}373(91 \%) \\
44(93 \%)\end{array}$ & $\begin{array}{l}37(9 \%) \\
9(7 \%)\end{array}$ & $\begin{array}{c}0.485(0.220-1.071) \\
1\end{array}$ & 0.074 \\
\hline
\end{tabular}

Table 4: Diet related factors associated with overweight among elementary school children in Addis Ababa, 2014. 
Children who eat when they watch TV has no association with overweight but children who do not eat while watching TV were $21.7 \%$ at lower risk of overweight than those who do not watch TV. Regarding eating breakfast regularly, children who eat breakfast regularly were at lower risk (32\%) than those who don't. Eating while studying was found to be strongly associated with overweight. Those who eat while studying were 3.3 times at higher risk than those do not (95\% CI 1.75 , $6.2)$.

\section{Physical activity and sedentary life style}

Activity related to job, and regular physical activity of the participants and the parent shows 245 (52.9\%) of the children do not participate in any work beside learning. $218(47.1 \%)$ participate in moderately intense work for at least 10 minute per day, only $12(2.6 \%)$ participate in vagarious activity for at least 10 minute per day. Out of 463 participant children 240 (51.8\%) walk or ride bicycle, 5-7/week, $154(33.3 \%)$ for 3-4 days per week, 40 (8.6\%) for 1-2 days/week while $29(6.3 \%)$ do not walk or ride bicycle at all. The participants physical activity status related sport and recreation revealed that $429(92.7 \%)$ participate in moderate physical exercise that cause minor increase heart rate and respiration. Activity performed in school during physical education period is incorporated moderate physical activity $29(6.3 \%)$ do vagarious /intense physical activity that cause major increase in HR and respiration for at least 10 minutes.

Sedentary behaviour of the participants was assessed by different questions. $82(17.7 \%)$ spend less than 6 hours sitting, $260(56.2 \%)$ spend 7-8 hours and 125 (26.1\%) spend 9 hours and more.

Physical activity related to work, sport, recreation and sedentary behaviour of the children in association with overweight is shown in table 5. According to the study children who do not participate in any work after school were $4.8(95 \% \mathrm{CI} 2.2,10.6)$ times at higher risk than those who do. Work that need medium energy decrease the risk of overweight by $20.8 \%$. Walking or riding bicycle was also found to be protective for overweight. It decreases the risk by $17.2 \%$. There is also strong association between strong vigorous intense sporting activity and overweight. Children who do not do strong physical activity are 3.2 times at higher risk those who do $(95 \%$ CI $0.43,24.8)$. Moderately intense sporting activity was found to increase the risk of overweight by $20.8 \%$.

Regarding recreation and playing, children who play in any playing station around their residence were found to be at lower risk of overweight. Those who do not paly were 5.6 times at higher risk than those who do $(95 \%$ CI2.4, 12.8). Sedentary behaviour of the child was also strongly associated with overweight. Children who sit more than 9 hours per day are 40 times at higher risk $(95 \%$ CI 6.4, 107) than those who sit 5-6 hours per day considering 4 and half hour school stay. Children from family where there is any member who perform regular physical activity are at lower risk of overweight. Those whose family members do not perform activity were 3.3 times at higher risk than those families do.

Finally binary logistic regression was done to control the effect of confounders. As it is indicated in the table 6, the following variable shows strong association; car ownership of the family $(p<0.001)$, number of snacks per day $(\mathrm{p}=0.03)$, sweet food preference $(\mathrm{p}<0.001)$, buying ice cream $(\mathrm{p}=0.014)$, eating breakfast regularly $(\mathrm{p}=0.034)$, walking or riding bicycle for at least 10 minutes per day $(\mathrm{p}=0.009)$ and family participation in regular physical activity $(\mathrm{p}=0.023)$.

Children who have family car to come from and go school were more likely to be overweight with AOR $28.2(5.3,68.5)$. When confounders were avoided children who prefer sweet food were found to be 25 times at higher risk than those who do not. High risk of overweight was also observed in children who buy ice cream whenever they got money. Walking or riding bicycle daily for at least 10 minute was found to protect overweight. Those children who don't walk or ride bicycle was 10.5 times at higher risk than those who do (AOR 10.5 $95 \%$ CI $(1.8,61.1)$ ). Family participation in regular physical activity was found to profoundly decrease the risk of overweight. In contrary to the fact and other study habit of buying cake was found to protect overweight $\mathrm{p}=0.04(\mathrm{AOR}=0.12,95 \% \mathrm{CI}(0.016,0.92))$.

\section{Discussion}

The study was conducted to assess the prevalence of childhood overweight and obesity and its determinants among elementary school children.

\section{Prevalence of overweight and/or obesity}

Our study revealed the overall prevalence of underweight, normal, overweight and obesity is 44 (9.5\%), 360 (77.8\%), 46 (9.9\%) and 13 $(2.8 \%)$ respectively. The prevalence of overweight in our study was found to be consistent with the study conducted in Addis Ababa, Arada

\begin{tabular}{|c|c|c|c|c|c|}
\hline \multirow{2}{*}{\begin{tabular}{|l|} 
Variable \\
Participation in work after school \\
\end{tabular}} & \multirow{2}{*}{$\begin{array}{l}\text { Level } \\
\text { Yes } \\
\text { No }\end{array}$} & \multicolumn{2}{|c|}{ Proportion } & \multirow{2}{*}{$\begin{array}{c}\text { COR(95\% Cl) } \\
1 \\
4.819(2.195-10.578)\end{array}$} & \multirow{2}{*}{$\begin{array}{l}\text { P value } \\
<0.001\end{array}$} \\
\hline & & $\begin{array}{l}210(96 \%) \\
207(84 \%)\end{array}$ & $\begin{array}{c}8(4 \%) \\
38(16 \%)\end{array}$ & & \\
\hline Medium energy work & $\begin{array}{l}\text { Yes } \\
\text { No }\end{array}$ & $\begin{array}{l}207(84 \%) \\
210(96 \%)\end{array}$ & $\begin{array}{c}38(16 \%) \\
8(4 \%)\end{array}$ & $\begin{array}{c}1 \\
0.208(0.095-0.456)\end{array}$ & $<0.001$ \\
\hline Walk or ride bicycle for at least 10 minute & $\begin{array}{l}\text { Yes } \\
\text { No }\end{array}$ & $\begin{array}{c}398(92 \%) \\
19(65 \%)\end{array}$ & $\begin{array}{c}36(8 \%) \\
10(35 \%)\end{array}$ & $\begin{array}{c}0.172(0.074-0.397) \\
1\end{array}$ & $<0.001$ \\
\hline Vigorous extensive exercise & $\begin{array}{l}\text { Yes } \\
\text { No }\end{array}$ & $\begin{array}{c}28(96 \%) \\
389(90 \%)\end{array}$ & $\begin{array}{c}1(4 \%) \\
45(10 \%)\end{array}$ & $\begin{array}{c}1 \\
3.239(0.430-24.37)\end{array}$ & 0.254 \\
\hline Moderately extensive exercise & $\begin{array}{l}\text { Yes } \\
\text { No }\end{array}$ & $\begin{array}{l}391(91 \%) \\
14(82 \%)\end{array}$ & $\begin{array}{l}38(9 \%) \\
3(18 \%)\end{array}$ & $\begin{array}{c}1 \\
0.208(0.095-0.456)\end{array}$ & $<0.001$ \\
\hline Playing and recreation around residence & $\begin{array}{l}\text { Yes } \\
\text { No }\end{array}$ & $\begin{array}{l}209(97 \%) \\
208(84 \%)\end{array}$ & $\begin{array}{c}7(3 \%) \\
39(16 \%)\end{array}$ & $\begin{array}{c}1 \\
5.598(2.448-12.802)\end{array}$ & $<0.001$ \\
\hline Number of hours spend sitting per day & $\begin{array}{l}5-6 \\
7-8 \\
\geq 9\end{array}$ & $\begin{array}{c}81(99 \%) \\
255(98 \%) \\
81(67 \%)\end{array}$ & $\begin{array}{c}1(1 \%) \\
5(2 \%) \\
40(33 \%)\end{array}$ & $\begin{array}{c}1 \\
1.588(0.183-13.793) \\
40.00(6.370-107.957)\end{array}$ & $\begin{array}{c}0.675 \\
<0.001\end{array}$ \\
\hline Family member who perform regular exercise & $\begin{array}{l}\text { Yes } \\
\text { No }\end{array}$ & $\begin{array}{l}120(96 \%) \\
297(88 \%)\end{array}$ & $\begin{array}{c}5(4 \%) \\
41(12 \%)\end{array}$ & $\begin{array}{c}1 \\
3.313(1.278-8.587)\end{array}$ & 0.014 \\
\hline
\end{tabular}

Table 5: Sport and physical activity related factor in association with overweight among elementary school children in Addis Ababa, 2014. 
Citation: Gebremichael B, Chere A (2015) Prevalence of Childhood Overweight and Obesity and its Determinant Factors Among Elementary School Children in Addis Ababa, Ethiopia: A Cross Sectional Study. J Nutr Disorders Ther S1: 002. doi:10.4172/2161- 0509.S1-002

\begin{tabular}{|c|c|c|c|}
\hline Variable & $\begin{array}{c}\text { Level } \\
\text { (Reference) }\end{array}$ & AOR $(95 \% \mathrm{Cl}$ & $P$ value \\
\hline School type & $\begin{array}{l}\text { Government } \\
\text { private }\end{array}$ & $\begin{array}{c}1 \\
2.3(0.5,10.9)\end{array}$ & 0.294 \\
\hline Car ownership of the family & $\begin{array}{l}\text { Yes } \\
\text { No }\end{array}$ & $\begin{array}{c}28.2(5.3,68.5) \\
1\end{array}$ & $<0.001$ \\
\hline Number of snacks per day & $\begin{array}{l}1 \text { times } \\
2 \text { times } \\
3 \text { times }\end{array}$ & $\begin{array}{c}1 \\
4.9(1.2,20.7) \\
9.6(0.5,78.7)\end{array}$ & $\begin{array}{l}0.029 \\
0.123\end{array}$ \\
\hline Eating while studying & $\begin{array}{l}\text { Yes } \\
\text { No }\end{array}$ & $\begin{array}{c}2.16(0.6,7.8) \\
1\end{array}$ & 0.242 \\
\hline Eating breakfast regularly & $\begin{array}{l}\text { Yes } \\
\text { No }\end{array}$ & $\begin{array}{l}0.12(0.01,0.85) \\
1\end{array}$ & 0.034 \\
\hline Sweet food preference & $\begin{array}{l}\text { Yes } \\
\text { No }\end{array}$ & $\begin{array}{c}25.4(6.6,96.9) \\
1\end{array}$ & $<0.001$ \\
\hline Vegetable preference & $\begin{array}{l}\text { Yes } \\
\text { No }\end{array}$ & $\begin{array}{c}1 \\
2.29(0.2,23.6)\end{array}$ & 0.486 \\
\hline $\begin{array}{l}\text { Food bought "cake (reference } \\
\text { No) } \\
{ }^{*} \text { Chocolate( reference No) } \\
\text { *Ice cream(reference No) }\end{array}$ & & $\begin{array}{c}0.12(0.016,0.92) \\
0.33(0.06,1.73) \\
12.4(1.7,82.1)\end{array}$ & $\begin{array}{l}0.041 \\
0.189 \\
0.014\end{array}$ \\
\hline $\begin{array}{l}\text { Participation in work after } \\
\text { school }\end{array}$ & $\begin{array}{l}\text { Yes } \\
\text { No }\end{array}$ & $\begin{array}{c}0.5(0.08,3.05) \\
1\end{array}$ & 0.454 \\
\hline $\begin{array}{l}\text { Walking or riding bicycle for } \\
\text { at least } 10 \text { minute per day. }\end{array}$ & $\begin{array}{l}\text { Yes } \\
\text { No }\end{array}$ & $\begin{array}{c}1 \\
10.5(1.8,61.1)\end{array}$ & 0.009 \\
\hline $\begin{array}{l}\text { Any family participates in } \\
\text { regular physical activity. }\end{array}$ & $\begin{array}{l}\text { Yes } \\
\text { No }\end{array}$ & $\begin{array}{l}0.2(0.05,0.8) \\
1\end{array}$ & 0.023 \\
\hline
\end{tabular}

* refers that no is the reference

Table 6: Multivariable logistic regression analysis of independent predictors of overweight among elementary school children in Addis Ababa, 2014.

sub city which was $9.4 \%$ [38]. But it was higher than the study done 7 years back in the same city which was $7.6 \%$ [9]. This could be explained by the change in the life style factors of the society. The prevalence of obesity in our study was $2.8 \%$. This is high proportion compared to the study conducted in Arada sub city, Addis Ababa which was $(0.8 \%)$ [38].The reason for this may be due to our study tries to incorporate all sub cities of the town in which people with high economic status may reside. Our study shows males are slightly obese than female but study done in Uganda shows females were more likely to be obese than male (2.9\% vs. $1.8 \%)$ [21].

Sex specific prevalence of overweight and obesity shows 17 (7.7\%) and $7(3.2 \%)$ of male participants were obese. Female participants were $29(12 \%)$ and $6(2.5 \%)$ overweight and obese respectively. High prevalence of overweight is recorded in female. This may be explained by our society culture in which females spent most of their time at home. The finding of this study is also consistent with some of the study done in African country. Study done in Douala, Cameron in 2010 , the prevalence of overweight ranges from $6.4 \%$ to $8.2 \%$ in boys and from $10.7 \%$ to $17.2 \%$ in girls, whereas prevalence of obesity ranges from $1.4 \%$ to $5.5 \%$ in boys and from 2.4 to $8.6 \%$ in girls. Prevalence of underweight according to WHO 2007 reference was higher in boys as compared to girls, $5.5 \%$ and $9.2 \%$ respectively [20]. The sex specific prevalence of underweight was almost equal in our study 22 (9.9\%) male and $22(9.1 \%)$ female. This proximate finding between our and Douala study may be due to the same socio economic and life style status of the population [39].

School type prevalence overweight shows 38 (18.2\%) and 8 (3.1\%) are overweight for private and government school respectively. The regression of this variable with overweight shows private school children were at higher risk to overweight than government school. They are 6.8 times at higher risk than government school students. This finding is comparable with that of Lebanese private school: a cross sectional study of adolescents in private Lebanese schools, aged 10-18 years indicates that overweight prevalence was $24.4 \%$ [40]. This high prevalence of overweight in private school is assumed to be due to high economic status of people in private school than government. People in the higher socioeconomic strata in the population were the most affected when obesity emerged in developing countries [39].

Study conducted in Addis Ababa showed the likelihood of overweight and/or obesity among adolescents increase as the age increase [38] this is the same as our study. Our study revealed out of 306 participant aged 10-14 years 29 (9.5\%) were overweight and out of 157 participant aged 15-18, 17 (10.8\%) were overweight.

\section{Determinants of overweight}

Over the last several decades, an increase in variety, availability, price and aggressive marketing have encouraged a shift in children's food choices from healthy foods such as fruit and vegetables to energydense, refined foods including fast-foods and sugar-laden beverages. The energy balance equation holds that obesity is the consequence of chronic positive energy imbalance $(16,28,29,30)$.

Our study revealed food bought by the participants like cake, biscuit, chocolate and ice cream has shown strong association with overweight (Table 4) when confounders were avoided only ice cream showed association. The study conducted in Addis Ababa in primary school children showed the same result [9]. From those food items ever bought by students, chocolate, ice cream and cake showed significant association with overweight. But in logistic regression analysis only ice cream revealed significant association.

The eating pattern of our respondent shows, eating while studying has significant association with overweight. Eating breakfast regularly was found to be protective for overweight. When binary logistic regression was done eating breakfast regularly has significant association. According to our study children who mention sweet food in their preference list was 29 times at high risk than those who don't. Fruit and vegetable preference was found to have positive association with overweight. The finding of our study is consistent with some study done recently. Systematic review of 16 studies from Europe has showed that eating based on schedule is associated with a reduced risk of becoming overweight or obese and a reduction in the BMI in children and adolescents. In UAE, Kerkrade found that $72.2 \%$ of non-obese female university students eat their breakfast regularly, and the rest (25.8\%) were either overweight or obese [13]. This association could be explained by the fact that skipping meals or failure to maintain a regular eating schedule can result in increased intakes and this problem is usually common in children and adolescents [28].

Physical activity related factors like work besides learning, doing extensively vigorous physical activity and playing in any recreation area around residence were found to have strong association with overweight. At the same time walking or riding bicycle for at least 10 minute per day and doing medium energy work was found to protect overweight by $17 \%$ and $21 \%$ respectively. When confounders were avoided only walking or riding bicycle has shown strong association. This result was consistent was the study conducted in Arada sub city in 2013 and in Addis Ababa in 2007 which found walking to school or riding bicycle for 30 minute per day decrease the risk of overweight significantly. Another study done in china also indicates the same 
finding that those who was walking to and from school, doing low intensity physical activity greater than 2 hours per day, doing moderate/ vigorous activity greater than 45 minutes per day were found to reduce risk of overweight $[41,42]$. This could be explained by walking to and from school and morning joggings provided a potentially important opportunity for establishing daily physical activity that have direct impact on decreasing overweight.

Physical activity levels of youth may depend on environmental features that encourage or discourage physical activity, such as access to recreational facilities, walkability of the environment and low neighbourhood crime rates [16]. The results of our study shows 247 (53.3\%) of the participants do not play around their residence. The reason mentioned by the participants were in availability of the places $168(36.2 \%)$ and not allowed by their parents 79 (17.1\%). The regression for activity related to recreation and playing around residence shows strong association with overweight. This could be explained by the fact that whenever there is no space to play around residence or children are not allowed to play, there is an increased risk of spending much time sedentarily which is found to be a major risk factor for overweight and obesity.

Children from family in which any family member participate in any regular physical activity were found to decrease the risk of overweight. Those who have no family member who participate in physical activity were 3 times more likely to be overweight than those who don't. Other studies also show the same finding. A recent review of 58 papers found fairly consistent associations between parental dietary intake and children's fat, fruit and vegetable consumption as well as physical activity since children might role model those behaviours of their parents $[16,28]$.

Sedentary behavior of the children was one of the variables that show amazingly strong association. Children who spent sitting more than 9 hours per day were 40 times more likely to be overweight than those who spend 5-6 hours per day (including 4 and $1 / 2$ hours sitting at school).This finding is almost similar with the study done in Addis Ababa which found significant association between sedentary behavior and overweight. Overweight increases together with sedentary behavior. Sedentary behavior greater than 9 hours per day (including 5 and $1 /$ hhour sitting at school), had the highest prevalence (17.1\%) [9]. Study done in china also showed the same finding. The prevalence of overweight among those whose physical inactivity less than or equal to 2 hours per day and greater than 2 hour per day was $4.9 \%$ and $7.3 \%$ respectively [42].

\section{Strength and limitation}

Our study has several strengths. This study used BMI as a criterion for classification which is mostly accepted and recommended to screen overweight and obesity for children aged 2-20 years. It is also the third in its kind to the country due to this reason it can motivate different researcher to do more investigation on overweight and obesity (the double burden of malnutrition in Ethiopia) and can also serve as a reference for future investigators.

Our study has also limitations. The study did not assess many other factors that influence the risk of childhood obesity. Weight gain during pregnancy, maternal obesity and birth weight have been shown to be strongly associated with childhood obesity $[8,22,29]$. Since the study is cross sectional it may not be strong to demonstrate direct cause and effect relationship between risk factors and outcome. During interview there might be a potential for recall and social desirability bias in the frequency of dietary habits, physical activity and sedentary behaviours of the participants. Also the food frequency questionnaire did not account for portion size. It is also possible that other unidentified confounders such as genetic factors may have influenced the findings of our study.

\section{Conclusions and Recommendation}

In conclusion, the findings of this study have shed light on the prevalence and determinants of obesity among primary school children in Addis Ababa. The prevalence of childhood obesity in this population was found to be low. However, the prevalence of overweight was found to be high even comparable with the global prevalence. Among the factors identified are unhealthy dietary pattern like preferring sweet foods, eating breakfast irregularly, buying ice cream and frequent snacking are strongly associated with overweight. In addition physical inactivity are also important factors impacting on the risk of obesity in children. If Primary preventive measures is not taken immediately, prevalence of overweight and obesity among children in Addis Ababa, might increase rapidly in the coming few years.

Based on the findings we suggest that promoting active lifestyles and healthy diets should be a national public health priority. There is a need of longitudinal study to investigate the relationship between vegetable intake and overweight and/or obesity. We also recommend further studies to be done to increase our understanding of genetic factors in relation to overweight and of the prenatal, perinatal and postnatal predictors of childhood obesity. Because early interventions on modifiable risk factors are likely to decrease the rate of childhood obesity, educational programs about obesity and associated health consequences should start early in childhood so as prevent the increasing prevalence of childhood obesity in Ethiopia.

\section{Abbreviations}

AAU: Addis Ababa University

AOR: Adjusted Odds Ratio

BMI: Body Mass Index

CDC: Centre for Disease Control

COR: Crude Odds Ratio

CI: Confidence Interval

EMR: Eastern Mediterranean Region

ETB: Ethiopian Birr

IOTF: International Obesity Task Force

OR: Odds Ratio

SPSS: Statistical Package for the Social Sciences

WHO: World Health Organization

\section{Competing Interests}

The authors declare that we have no competing interests.

\section{Authors' Contributions}

Both of the authors (BG \& AC) contributed to the design of the study and the interpretation of data. BG performed the data analysis and drafted the manuscript. Both authors critically revised the draft manuscript. Both authors read and approved the final manuscript. 
Citation: Gebremichael B, Chere A (2015) Prevalence of Childhood Overweight and Obesity and its Determinant Factors Among Elementary School Children in Addis Ababa, Ethiopia: A Cross Sectional Study. J Nutr Disorders Ther S1: 002. doi:10.4172/2161- 0509.S1-002

\section{Acknowledgment}

First of all, we would like to express our deepest gratitude and appreciation for Addis Ababa University for financial support to undertake this research work. We would also like to express our gratitude to officers from Addis Ababa Education bureau for giving permission and the necessary information. Our thanks also go to AAU, medical faculty, community health librarians for their valuable support by giving all the necessary literatures. We would also like to extend our appreciation to the data collectors and supervisors who participated in the study. We are also grateful to all study subjects who participated in the study.

\section{References}

1. WHO (2006) Global Strategy on diet, physical activity and health.

2. WHO Media Centre (2006). Fact sheet: Obesity and overweight.

3. World Health Organization (2008). WHO Africa region: Global database on body mass index.

4. Lobstein T, Baur L, Uauy R; IASO International Obesity TaskForce (2004) Obesity in children and young people: a crisis in public health. Obes Rev 5 Suppl 1: 4-104.

5. Wang Y, Ge K, Popkin BM (2000) Tracking of body mass index from childhood to adolescence: a 6-y follow-up study in China. Am J Clin Nutr 72: 1018-1024.

6. de Onis M, Blössner M (2000) Prevalence and trends of overweight among preschool children in developing countries. Am J Clin Nutr 72: 1032-1039.

7. Joint WHO/FAO Expert Consultation on Diet, Nutrition and the Prevention of Chronic Diseases (2002)

8. Centre for advancement of health, looming chronic disease creates double burden in Africa (2006)

9. Zeleke G (2007) Prevalence of childhood and adolescent overweight and obesity among elementary school children in Addis Ababa. Addis Ababa University digital library.

10. World Health Organization (WHO) (1998) Obesity and managing the global epidemic. WHO Technical Report Series 894, WHO, Geneva, Switzerland.

11. Kosti RI, Panagiotakos DB (2006) The epidemic of obesity in children and adolescents in the world. Cent Eur J Public Health 14: 151-159.

12. Krebs NF, Jacobson MS; American Academy of Pediatrics Committee on Nutrition (2003) Prevention of pediatric overweight and obesity. Pediatrics 112: 424-430.

13. [No authors listed] (1995) Physical status: the use and interpretation of anthropometry. Report of a WHO Expert Committee. World Health Organ Tech Rep Ser 854: 1-452.

14. CDC, safer Healthier people overweight children and adolescents Recommendation to screen, assess and manage.

15. Smoak CG, Burke GL, Webber LS, Harsha DW, Srinivasan SR, et al. (1987) Relation of obesity to clustering of cardiovascular disease risk factors in children and young adults. The Bogalusa Heart Study. Am J Epidemiol 125: 364-372.

16. Spruijt-Metz D (2011) Etiology, Treatment and Prevention of Obesity in Childhood and Adolescence: A Decade in Review. J Res Adolesc 21: 129-152.

17. Public health access (2011) USA, California.

18. Bracale R, Milani L, Ferrara E, Balzaretti C, Valerio A, et al. (2013) Childhood obesity, overweight and underweight: a study in primary schools in Milan. Eat Weight Disord 18: 183-191.

19. O-Musaiger A (2004) Overweight and obesity in the Eastern mediterranean Region, Eastern Mediterranean Health Journal 10.

20. Muhihi AJ, Mpembeni RN, Njelekela MA, Anaeli A, Chillo O, et al. (2013) Prevalence and determinants of obesity among primary school children in Dar es Salaam, Tanzania. Arch Public Health 71: 26.
21. Wamba PC, Enyong Oben J, Cianflone K (2013) Prevalence of overweight, obesity, and thinness in Cameroon urban children and adolescents. J Obes 2013: 737592

22. Baalwa J, Byarugaba BB, Kabagambe EK, Otim AM (2010) Prevalence of overweight and obesity in young adults in Uganda. Afr Health Sci 10: 367-373.

23. Kolbo JR, Penman AD, Meyer MK, Speed NM, Molaison EF, et al. (2006) Prevalence of overweight among elementary and middle school students in Mississippi compared with prevalence data from the Youth Risk Behavior Surveillance System. Prev Chronic Dis 3: A84.

24. Tounian $P$ (2004) Body weight regulation in children: a key to obesity physiopathology understanding. Arch Pediatr 11: 240-244.

25. Knerr I, Topf HG, Hablawetz B, Stöhr W, Dötsch J, et al. (2005) Early factors influencing body weight and prevalence of overweight in 4610 children prior to school entry in the Erlangen District (Northern Bavaria). Germany 67: 183-188.

26. Anthony JG Hanley (2000) over weight among children and adolescents native Canadian community prevalence and associated factors. American journal of clinical nutrition 71: 693-700.

27. Rooney BL, Mathiason MA, Schauberger CW (2011) Predictors of obesity in childhood, adolescence, and adulthood in a birth cohort. Matern Child Health J 15: 1166-1175

28. Epstein LH, Goldfield GS (1999) Physical activity in the treatment of childhood overweight and obesity: current evidence and research issues. Med Sci Sports Exerc 31: S553-559.

29. NAASO, The obesity society, childhood overweight.

30. The Connecticut centre for health. Obesity and overweight.

31. Parliamentary office of science and technology (2003) Childhood obesity. 205

32. Australian Government Department of health (2002) About overweight and obesity.

33. Weight -control information Network. Statistics related to overweight and obesity.

34. The surgeon Generals call to prevent and decrease overweight and obesity. Overweight and obesity: Health consequences.

35. The Australasian Society for study of obesity (2005) What are the consequences of overweight and obesity?

36. Kim HM, Park J, Kim H, Kim DH, Park SH (2006) Obesity and cardiovascula risk factors in Korean children and adolescents aged 10-18 years from the Korean National Health and Nutrition examination survey, 1998 and 2001 America Journal of Epidemiology 164: 787-793.

37. International obesity task force (IOTF) (2003) Obesity and diabetes, London

38. WHO (2002) Childhood nutrition and progress in implementing the international code of marketing of breast-milk substitutes, 15th world heath Assembly, agenda item 13: 10.

39. Alemu E, Atnafu A, Yitayal M, Yimam K (2014) Prevalence of Overweight and/ or Obesity and Associated Factors among High School Adolescents in Arada Sub city, Addis Ababa, Ethiopia. J Nutr Food Sci 4: 261.

40. Caballero B (2007) The global epidemic of obesity: an overview. Epidemiol Rev 29: 1-5.

41. Chakar H, Salameh PR (2006) Adolescent obesity in Lebanese private schools Eur J Public Health 16: 648-651.

42. Martorell R, Kettel Khan L, Hughes ML, Grummer-Strawn LM (2000) Overweigh and obesity in preschool children from developing countries. Int J Obes Related Metabolic Disorders Journal of the International Association for the Study of Obesity 24: 959-967. 